\title{
DECISION SUPPORT SYSTEM DENGAN METODE AHP, SAW DAN ROC UNTUK PENENTUAN PEMBERIAN BEASISWA (STUDI KASUS : STMIK STIKOM INDONESIA)
}

\author{
I Gede Iwan Sudipa \\ Prodi Teknik Informatika, STMIK STIKOM Indonesia \\ iwansudipa@stiki-indonesia.ac.id
}

\begin{abstract}
STIKOM STIMIK Indonesia (STIKI) is one of the university that provides scholarships for students, manual assessment have the weakness that is inefficient and potentially not objective, in addition to supporting the principles of the right on target scholarships then the selection criteria should be in detailed model so that the scholarship grantee is a student in accordance with the criteria or requirements that have been determined. In fulfilling the principles of the right on target and objective assessment, this research used MADM model by combining the Analytic Hierarchy Process (AHP), Rank Order Centroid (ROC) and Simple Additive Weighting (SAW). $A H P$ is used to determine the weighting of criteria and sub criteria, the ROC is used to determine the scoring championship level and championship field,interpolation is used to determine the value of salary data and electrical power, while $S A W$ is used to find the final result and determining the rank. Result of this research show thats the same best alternative for scholarship receipts between manual calculations, system calculations and STIKI calculations. Differences result of the rank on some alternate sequence due to difference in weight is given and difference criteria used. Resulted of rank in this research that can serve as recommendations for Puket III todetermining scholarship PPA and BBP recipients.
\end{abstract}

Keywords: $M A D M, A H P, R O C$, SAW,Linear Interpolation, Scholarship

\begin{abstract}
ABSTRAK
STIKOM Indonesia (STIKI) merupakan salah satu lembaga pendidikan perguruan tinggi yang memberikan beasiswa PPA dan BBP kepada mahasiswanya, penilaian secara manual memiliki kelemahan yaitu tidak efisien dan berpotensi tidak obyektif, disamping itu untuk menunjang prinsip tepat sasaran pemberian beasiswa maka kriteria yang digunakan dalam seleksi harus dimodelkan dengan detail sehingga penerima beasiswa merupakan mahasiswa yang sesuai dengan kriteria-kriteria atau persyaratan yang telah ditentukan. Dalam mendukung prinsip tepat sasaran dan penilaian lebih obyektif maka penelitian ini menggunakan model MADM dengan menggabungkan Analytic Hierarchy Process (AHP), Rank Order Centroid (ROC) dan Simple Additive Weighting (SAW). AHP digunakan untuk menentukan bobot kriteria dan sub kriteria, ROC digunakan untuk menentukan skoring data tingkat kejuaraan dan bidang kejuaraan, interpolasi digunakan untuk menentukan nilai dari data gaji dan daya listrik, sedangkan metode SAW digunakan untuk mencari nilai akhir dan perankingan. Hasil dari penelitian ini menunjukkan alternatif terbaik yang sama untuk perhitungan sistem, perhitungan manual, serta perhitungan yang dilakukan pada STIKI. Perbedaan perankingan pada beberapa urutan alternatif disebabkan karena perbedaan bobot yang diberikan dan perbedaan kriteria yang digunakan. Hasil perankingan penelitian dapat dijadikan rekomendasi untuk Puket III dalam menentukan mahasiswa penerima beasiswa
\end{abstract}

Kata Kunci : MADM, AHP, ROC, SAW, Interpolasi Linear, Beasiswa 


\section{PENDAHULUAN}

Salah satu permasalahan pendidikan di Indonesia adalah tingginya biaya pendidikan khususnya untuk memperoleh gelar sarjana, sehingga pemerintah melalui perguruan tinggi negeri atau swasta, yayasan atau perusahaan swasta, mengalokasikan dana untuk memberikan bantuan biaya pendidikan kepada mahasiswa yang orangtuanya tidak mampu untuk membiayai dan mahasiswa yang mempunyai prestasi tinggi, baik akademik maupun non akademik dalam bentuk beasiswa, salah satunya beasiswa beasiswa Peningkatan Prestasi Akademik (PPA) dan Bantuan Biaya Pendidikan Peningkatan Prestasi Akademik (BBP PPA). Pelaksanaan program beasiswa ini sesuai dengan prinsip 3T yaitu Tepat Sasaran, Tepat Jumlah, dan Tepat Waktu.

STIKOM Indonesia (STIKI) merupakan salah satu lembaga pendidikan perguruan tinggi yang memberikan beasiswa PPA dan BBP kepada mahasiswanya, penilaian secara manual yang masih dilakukan memiliki kelemahan yaitu tidak efisien, sehingga diperlukan sistem yang dapat meningkatkan efektivitas dalam proses seleksi dengan banyak atribut kriteria untuk menjadi penentu dalam proses seleksi alternatif penerima beasiswa, maka diperlukan sistem pendukung keputusan guna meningkatkan efektifitas pengambilan keputusan, mengakomodasi pemodelan yang sesuai dengan prinsip tepat sasaran dan penilaian lebih obyektif.SPK biasanya dibangun untuk mendukung solusi atas suatu masalah atau mengevaluasi suatu peluang [1].

Pengambilan keputusan dalam permasalahan beasiswa PPA dan BBM menggunakan kriteria prestasi akademik, kegiatan pendukung lainnya dan faktor ekonomi, dimana setiap kriteria memiliki subkriteria yang menentukan hasil keputusan pemberian beasiswa. Pengambilan keputusan menajerial yang tepat dapat memberikan alternatif keputusan penerima beasiswa sehingga membantu Pembantu Ketua III (Puket III) STIKI Indonesia dalam

\section{TINJAUAN PUSTAKA}

\section{Sistem Pendukung Keputusan}

Sistem pendukung keputusan menunjukkan sebuah sistem yang mendukung para pengambil keputusan untuk memperluas kapabilitas mereka, namun proses pengambilan keputusan dengan mempertimbangkan berbagai faktor-faktor yang harus dipertimbangkan secara obyektif, rasional dan proporsional dalam penilaian pemberian beasiswa.

Penelitian mengenai seleksi pemberian beasiswa pernah dilakukan oleh Yeh dan Willis[2] yang menjelaskan menjelaskan seleksi pemberian beasiswa dari beberapa alternatif atau kandidat merupakan suatu proses pembuatan keputusan yang kompleks, karena beberapa kriteria harus dipertimbangkan secara bersamaan dalam proses pemilihan, sehingga masalah seleksi pemberian beasiswa dirumuskan sebagai masalah MADM, pendekatan pembuatan keputusan dengan model MADM telah terbukti efektif untuk melakukan perankingan atau menyeleksi satu atau lebih dari sejumlah alternatif yang terbatas terhadap beberapa kriteria atau atribut yang biasanya bertentangan. Keeney dan Raiifa [3] menjelaskan bahwa pengambilan keputusan dimulai dengan membangun model MADM yaitu mengidentifikasi tujuan, menurunkan kriteria-kriteria, menentukan bobot dan perankingan.

Pada penelitian ini menggunakan model MADM dengan perbandingan metode AHPSAW dan metode ROC-SAW. Metode AHP dan ROC digunakan untuk menentukan bobot kriteria dan subkriteria,serta metode SAW digunakan untuk mencari nilai akhir alternatif penerima beasiswa dan perankingan. Metode AHP dipilih karena dapat membantu dalam menentukan bobot preferensi terhadap kriteria dan subkriteria yang digunakan yang akan digunakan dalam proses perhitungan metode SAW agar lebih efektif, perhitungan ROC selain sangat sederhana namun dapat digunakan dalam penentuan bobot dengan banyak atribut kriteria sehingga nilainya diperoleh dan dapat digunakan dalam proses perhitungan nilai akhir. Metode SAW digunakan karena dapat melakukan perankingan secara cepat dan tepat, namun tetap memperhitungan sifat atribut yang saling bertentangan[5].

tidak menggantikan penilaian mereka. Sistem pendukung keputusan merupakan sistem informasi interaktif yang menyediakan informasi, pemodelan dan manipulasi data. Sistem itu digunakan untuk membantu pengambil keputusan dalam situasi yang semistruktural dan situasi yang 
tidak terstruktural, dimana tidak seorangpun tahu secara pasti bagaimana keputusan seharusnya dibuat [6].

Ada tiga tujuan yang harus dicapai dalam sebuah sistem pendukung keputusan [7], yaitu :

- Membantu manajer membuat keputusan untuk memecahkan masalah semistruktural dengan alternatif keputusan yang diberikan.

- Mendukung penilaian manajer, bukan mencoba menggantikannya.

- Meningkatkan efektifitas pengambilan keputusan manajer daripada efisiensinya.

\section{AHP (Analytic Hierarchy Process)}

Saaty menyatakan bahwa AHP adalah suatu metode yang unggul untuk memilih aktifitas bersaing dengan menggunakan kriteria khusus. Kriteria dapat bersifat

kuantitatif dan kualitatif. Kelebihan AHP diantaranya adalah berdasar pada matriks perbandingan berpasangan dan melakukan analisis konsistensi [8]. Perbandingan berpasangan merupakan bagian yang terpenting dari metode AHP, dimana pemberian nilai perbandingan berpasangan ini harus dilakukan oleh yang ahli di bidangnya [9].

\section{- Prosedur AHP}

Prosedur yang dilakukan pada tahap ini adalah : menentukan kriteria dari alternatifalternatif yang kemudian menyusunnya menjadi satu hirarki. Membuat matriks pairwise comparison berdasarkan kriteria dan alternatif dengan skala penilaian sehingga akan diperoleh nilai pendapat dalam bentuk angka, skala perbandingan berdasarkan [3], berikut tabel 1 dibawah ini :

Tabel 1. Skala Matriks Pairwaise Comparation

\begin{tabular}{|c|c|c|}
\hline Kepentingan & Definisi & Penjelasan \\
\hline 1 & Kedua elemen sama penting & $\begin{array}{l}\text { Dua elemen mempunyai pengaruh } \\
\text { yang sama besar terhadap tujuan }\end{array}$ \\
\hline 3 & $\begin{array}{l}\text { Elemen yang satu sedikit } \\
\text { lebih penting daripada elemen } \\
\text { yang lainnya }\end{array}$ & $\begin{array}{l}\text { Pengalaman dan penilaian sedikit } \\
\text { menyokong satu elemen dibanding } \\
\text { elemen lainnya }\end{array}$ \\
\hline 5 & $\begin{array}{l}\text { Elemen yang satu lebih } \\
\text { penting daripada elemen yang } \\
\text { lainnya }\end{array}$ & $\begin{array}{l}\text { Pengalaman dan penilaian dengan } \\
\text { kuat menyokong satu elemen } \\
\text { dibanding elemen lainnya }\end{array}$ \\
\hline 7 & $\begin{array}{l}\text { Satu elemen jelas lebih } \\
\text { penting daripada elemen yang } \\
\text { lainnya }\end{array}$ & $\begin{array}{l}\text { Satu elemen yang kuat disokong } \\
\text { dan domain terlihat dalam } \\
\text { kenyataan }\end{array}$ \\
\hline 9 & $\begin{array}{l}\text { Satu elemen mutlak lebih } \\
\text { penting daripada elemen yang } \\
\text { lainnya }\end{array}$ & $\begin{array}{l}\text { Bukti yang mendukung elemen } \\
\text { yang satu terhadap elemen lain } \\
\text { memiliki tingkat penegasan } \\
\text { tertinggi menguatkan }\end{array}$ \\
\hline $2,4,6,8$ & $\begin{array}{lrr}\text { Nilai-nilai } & \text { diantara } & \text { dua } \\
\text { pertimbangan } & & \text { yang } \\
\text { berdekatan } & & \\
\end{array}$ & $\begin{array}{l}\text { Nilai ini diberikan bila ada dua } \\
\text { komponen diantara dua pilihan }\end{array}$ \\
\hline Kebalikan & $\begin{array}{lr}\text { Jika aktifitas } i & \text { mendapat satu } \\
\text { angka bila dibandingkan } \\
\text { dengan aktifitas } j, & \text { maka } j \\
\text { mempunyai } & \text { nilai } \\
\text { kebalikannya } & \text { bila } \\
\text { dibandingkan } i & \\
\end{array}$ & \\
\hline
\end{tabular}

Prosedur dasar AHP terdiri dari beberapa langkah sebagai berikut[10]:

1. Membuat matriks perbandingan berpasangan

Tabel 2. Matriks Perbandingan Berpasangan

\begin{tabular}{|c|c|c|c|c|}
\hline $\mathrm{K}$ & $\mathrm{K} 1$ & $\mathrm{~K} 2$ & $\ldots$ & $\mathrm{Kn}$ \\
\hline $\mathrm{K} 1$ & $\mathrm{~b} 11$ & $\mathrm{~b} 12$ & $\ldots$ & $\mathrm{b} 1 \mathrm{n}$ \\
\hline $\mathrm{K} 2$ & $\mathrm{~b} 21$ & $\mathrm{~b} 22$ & $\ldots$ & $\mathrm{b} 2 \mathrm{n}$ \\
\hline$\ldots$ & $\ldots$ & $\ldots$ & bij & $\ldots$ \\
\hline $\mathrm{Kn}$ & bn1 & bn2 & $\ldots$ & bnn \\
\hline
\end{tabular}

Mengalikan masing-masing element pada masing-masing baris matriks perbandingan, dan hasilnya adalah $\mathrm{M}_{\mathrm{i}}$ dengan menggunakan persamaan $\mathrm{M}_{\mathrm{i}}=$

$$
\prod_{j=1}^{n} b, \mathrm{i}=1,2, \ldots, \mathrm{n}
$$

2. Menghitung $\mathrm{n}$ akar pangkat dari $\mathrm{Mi}$ dengan persamaan

$$
\bar{W}=\sqrt[n]{M_{\mathrm{i}}}, \mathrm{i}=1,2, \ldots, \mathrm{n}
$$

3. Melakukan normalisasi terhadap $\bar{W}_{\mathrm{i}}$ dengan persamaan

$$
\mathrm{W}_{\mathrm{i}}=\bar{W}_{\mathrm{i}} / \sum_{j=1}^{n} \bar{W}_{\mathrm{j}}, \mathrm{i}=1,2, \ldots, \mathrm{n}
$$


4. Mencari nilai lamda maks. Menurut Saaty[8], mencari $\lambda_{\text {maks }}$ dapat menggunakaan persamaan

$$
\lambda_{\text {maks }}=\sum_{i=1}^{n} \frac{W i}{n * W i}
$$

5. Cek Consistency Index (CI)

Tabel 3. Random Index (RI)

persamaan $\mathrm{CI}=\frac{\lambda_{m}-n}{n-1}$

\begin{tabular}{|c|c|c|c|c|c|}
\hline $\begin{array}{c}\text { Ordo } \\
\text { Matriks }\end{array}$ & RI & $\begin{array}{c}\text { Ordo } \\
\text { Matriks }\end{array}$ & RI & $\begin{array}{c}\text { Ordo } \\
\text { Matriks }\end{array}$ & RI \\
\hline 1 & 0 & 6 & 1,24 & 11 & 1,51 \\
\hline 2 & 0 & 7 & 1,32 & 12 & 1,48 \\
\hline 3 & 0,58 & 8 & 1,41 & 13 & 1,56 \\
\hline 4 & 0,9 & 9 & 1,45 & 14 & 1,57 \\
\hline 5 & 1,12 & 10 & 1,49 & 15 & 1,59 \\
\hline
\end{tabular}

7. Mencari CR (Consistency Ratio)

$\mathrm{CR}=\frac{C}{R}$, Jika nilai $\mathrm{CR}<0.1$ berarti data

perbandingan yang dibuat sudah

konsisten.

\section{ROC (Rank Order Centroid)}

Barron dan Barret menjelaskan bahwa perhitungan ROC untuk menentukan bobot pengganti (elicitation weight) dari urutan prioritas atribut yang ditentukan oleh pengambil keputusan, ROC didasarkan pada tingkat kepentingan atau prioritas yang biasanya dibentuk dengan pernyataan "atribut ke-1 lebih penting dari atribut ke-2, yang lebih penting dari kriteria ke-3 dan seterusnya hingga atribut ke-n" [10].

Dalam perhitungan ROC, untuk menentukan bobot maka diberikan aturan :

\section{SAW (Simple Additive Weighting)}

Konsep dasar metode SAW adalah mencari penjumlahan terbobot dari rating kinerja pada setiap alternatif pada semua atribut. Metode SAW membutuhkan proses normalisasi matriks keputusan (X) ke dalam suatu skala yang dapat diperbandingkan dengan semua rating alternatif yang ada. Metode SAW mengharuskan pembuat keputusan menentukan bobot bagi setiap atribut. Skor total untuk alternatif diperoleh dengan menjumlahkan seluruh hasil perkalian antara rating dan bobot tiap atribut. Rating tiap atribut harulah dimensi
6. Mencari Nilai RI disesuaiakan dengan nilai Random Index yang dapat dilihat pada Tabel 3 dibawah ini.

$$
W_{l} \geq W_{2} \geq W_{3} \geq \ldots \geq W_{n} \geq
$$

$0 ; \sum_{j=1}^{n} \bar{W}_{\mathrm{j}}=1$

Dimana $W_{l}$ merupakan bobot untuk semua kriteria $C_{l}$, sehingga nilai $W_{l}$ sampai $W_{j}$ dapat ditentukan sebagai berikut :

$$
\begin{aligned}
& W_{1}=\left(1+\frac{1}{2}+\frac{1}{3}+\ldots+\frac{1}{j}\right) / \mathrm{K} \\
& W_{2}=\left(0+\frac{1}{2}+\frac{1}{3}+\ldots+\frac{1}{j}\right) / \mathrm{K} \\
& W_{j}=\left(0+\ldots+0+\frac{1}{j}\right) / \mathrm{K}
\end{aligned}
$$

Secara umum jika $\mathrm{K}$ adalah jumlah kriteria, maka nilai bobot kriteria ke-j dirumuskan dengan mengalikan $1 / \mathrm{K}$ dengan jumlah total $1 / i$, dimana $i=1,2,3 . ., \mathrm{j}$, sebagai berikut :

$$
\begin{aligned}
& \mathrm{W}_{\mathrm{j}}=\frac{1}{\mathrm{~K}} \sum_{i=1}^{\mathrm{K}}\left(\frac{1}{i}\right) \\
& W j=\text { nilai pembobotan atribut ke- } j \\
& \mathrm{~K}=\text { jumlah atribut } \\
& i=\text { nilai urutan prioritas atribut }
\end{aligned}
$$

dalam arti telah melewati proses normalisasi matriks sebelumnya [11].

Pada penelitian ini tentang seleksi pemberian beasiswa, maka mahasiswa yang memiliki nilai akhir tertinggi yang akan menjadi prioritas sebagai alternatif terbaik penerima beasiswa PPA ataupun BBP. Terdapat tahapan-tahapan yang harus dilakukan, yaitu :

1. Penentuan nilai kriteria

Perhitungan dilakukan dengan menggunakan persamaan :

$N=\sum(S * X)$

Keterangan :

NK: Nilai total tiap kriteria

SK : Nilai subkriteria 
$\mathrm{X}$ : Besar bobot preferensi

2. Membuat matriks keputusan

Matriks keputusan dibuat berdasarkan jumlah elemen (n) kriteria dan jumlah alternatif.

3. Normalisasi Matriks

Metode SAW membutuhkan proses normalisasi matriks keputusan $\mathrm{X}$ ke suatu skala yang dapat diperbandingkan dengan semua rating alternatif yang ada. Perhitungan untuk melakukan normalisasi matriks disesuaikan dengan persamaan

$$
\mathrm{r}_{\mathrm{ij}}=\frac{X}{M}
$$

jika atribut termasuk keuntungan

$$
\mathrm{r}_{\mathrm{ij}}=\frac{M}{X}
$$

jika atribut termasuk biaya

Keterangan :

$\mathrm{r}_{\mathrm{ij}}=$ rating kinerja ternormalisasi

$\operatorname{MaxX}_{\mathrm{ij}}=$ nilai maksimum elemen tiap kriteria

$$
\begin{aligned}
& \operatorname{Min}_{\mathrm{ij}} \quad=\text { nilai minimum } \\
& \text { elemen tiap kriteria } \\
& \text { Benefit }=\text { jika nilai } \\
& \text { terbesar adalah yang terbaik } \\
& \text { Cost }=\text { jika nilai } \\
& \text { terkecil adalah yang terbaik }
\end{aligned}
$$

\section{ANALISIS DAN PERANCANGAN \\ Pengumpulan Data}

Tahap pengumpulan data dilakukan dengan observasi, wawancara dan studi pustaka. Observasi dan wawancara dilakukan untuk mengumpulkan data dan informasi langsung dari STIKI Indonesia seperti data mahasiswa pemohon beasiswa PPA dan BBM, data kriteria-kriteria dan bobot. Wawancara dilakukan dengan Pembantu Ketua III (Puket III) STIKI Indonesia. Sedangkan untuk studi pustaka dalam memahami konsep dan penerapan metode AHP, SAW dan ROC, penulis melakukan studi literatur melalui internet dan buku-buku yang relevan.
4. Perhitungan nilai akhir dan perankingan Dimana $r_{i j}$ adalah rating kinerja ternormalisasi dari setiap alternatif $\mathrm{A}_{\mathrm{i}}$ pada atribut $\mathrm{C}_{\mathrm{j}}, \mathrm{i}=1,2, \ldots \mathrm{m}$ dan $\mathrm{j}=$ $1,2, . .$, n. Nilai preferensi untuk setiap alternatif $\left(\mathrm{V}_{\mathrm{i}}\right)$ diberikan sebagai berikut :

$$
\begin{aligned}
& V_{i}=\sum_{j=1}^{n} w_{j} r_{i} \\
& \text { Keterangan : } \\
& \mathrm{V}_{\mathrm{i}}=\text { rangking untuk setiap alternatif } \\
& \mathrm{w}_{\mathrm{j}}=\text { nilai bobot dari setiap kriteria } \\
& \mathrm{r}_{\mathrm{ij}}=\text { nilai rating kinerja }
\end{aligned}
$$

ternormalisasi

Nilai $\mathrm{V}_{\mathrm{i}}$ lebih besar mengindikasikan bahwa alternatif $\mathrm{A}_{\mathrm{i}}$ lebih terpilih.

\section{Interpolasi Linear}

Pada penelitian nilai penghasilan orangtua dan daya listrik akan dirubah menggunakan interpolasi linier, Persamaan dari interpolasi linear sebagai berikut :

$$
y=\frac{y_{1}-y_{0}}{x_{1}-x_{0}}\left(x-x_{0}\right)+y_{0}
$$

Dimana $y_{l}$ merupakan batas atas skor, $y_{0}$ adalah batas bawah skor, $x_{1}$ adalah batas bawah penghasilan orangtua, $x_{0}$ adalah batas bawah penghasilan orangtua, dan $x$ adalah nilai penghasilan orangtua yang akan ditentukan nilai interpolasinya.

\section{Tahap Analisa awal}

Pada tahap ini dilakukan analisa kriteria dan subkriteria yang digunakan dan penerapan metode dalam studi kasus pemberian beasiswa PPA dan BBM. Terdapat dua penerapan metode dalam studi kasus yaitu metode AHP-SAW dan ROC-SAW, kemudian kedua hasil metode akan dibandingkan dihitung akurasinya sehingga akan diketahui metode yang tepat dan akurat dalam menghasilkan alternatif penerima beasiswa yang paling sesuai dengan kriteria dan subkriteria penilaian. Berikut tabel 4 penjelasan kriteria dan subkriteria yang digunakan dalam penelitian : 
Tabel 4. Sifat kriteria dan sub kriteria

\begin{tabular}{|c|l|l|c|}
\hline Variabel & \multicolumn{1}{|c|}{ Kriteria } & \multicolumn{1}{|c|}{ Sub kriteria } & Sifat \\
\hline K1 & Prestasi akademik & IPK & Benefit \\
\hline SK1 & & Kejuaraan akademik & Benefit \\
\hline SK2 & & Lama studi & Benefit \\
\hline SK3 & & & \\
\hline K2 & Kegiatan Pendukung Lainnya & Prestasi non akademik & Benefit \\
\hline SK4 & & Banyaknya seminar & Benefit \\
\hline SK5 & Faktor ekonomi & Penefit \\
\hline SK6 & & Tanggungangan orangtua & Benefit \\
\hline K3 & & Daya listrik & Cost \\
\hline SK7 & & & Cost \\
\hline SK8 & &
\end{tabular}

\section{Proses Perancangan model Keputusan}

Pada proses ini dilakukan dengan menyusun hirarki seleksi pemberian beasiswa yaitu mendefinisikan masalah dan membentuk solusi yang di inginkan, dilanjutkan dengan membuat hirarki yang diawali dengan tujuan umum, kriteria, sub kriteria dan alternatif-alternatif, seperti yang dijelaskan pada Gambar 1 sebagai berikut :

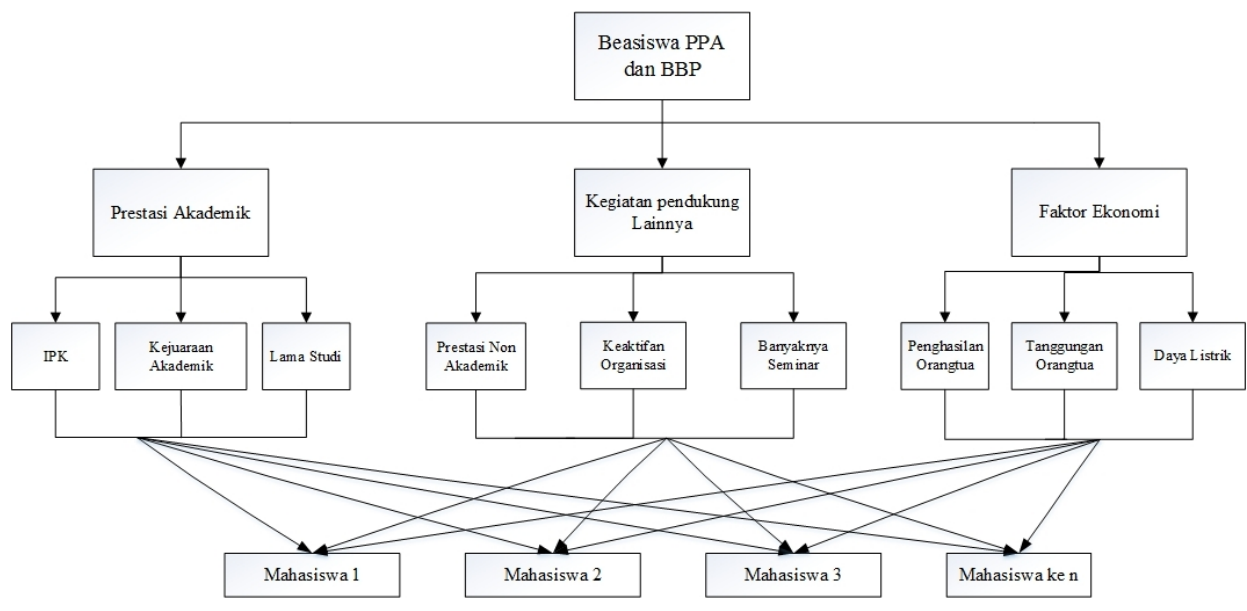

Gambar 1. Hirarki seleksi pemberian beasiswa BBP

Gambar 1 menunjukkan hirarki seleksi pemberian beasiswa PPA dan BBP sehingga dapat diketahui bahwa tujuan yang ingin dicapai dalam sistem ini adalah pemberian beasiswa PPA kepada mahasiswa. Adapun kriteriayang digunakan dalam proses seleksi pemberian beasiswa terdiri dari prestasi akademik, kegiatan pendukung lainnya dan faktor ekonomi. Untuk kriteria prestasi akademik memiliki atribut subkriteria yaitu IPK, kejuaraan atau lomba akademik dan lama studi.Kriteria kegiatan pendukung lainnya memiliki atribut sub kriteria yaitu prestasi non akademik, keaktifan organisasi dan banyaknya seminar yang diikuti. Kriteria faktor ekonomi memiliki atribut sub kriteria yaitu penghasilan orangtua, tanggungan orangtua dan daya listrik.

Model Sistem Pendukung Keputusan

Model yang digunakan dalam penelitian ini adalah model MADM dengan metode AHP untuk menentukan bobot kriteria, sub kriteria yang akan digunakan untuk perhitungan nilai akhir. Perhitungan ROC untuk menentukan nilai bobot untuk tingkat kejuaraan dan bidang kejuaraan. Metode SAW digunakan perhitungan nilai akhir dan perangkingan alternatif penerima beasiswa. Gambaran umum model SPK untuk pemberian beasiswa PPA dan BBP dapat dilihat pada Gambar 2. 


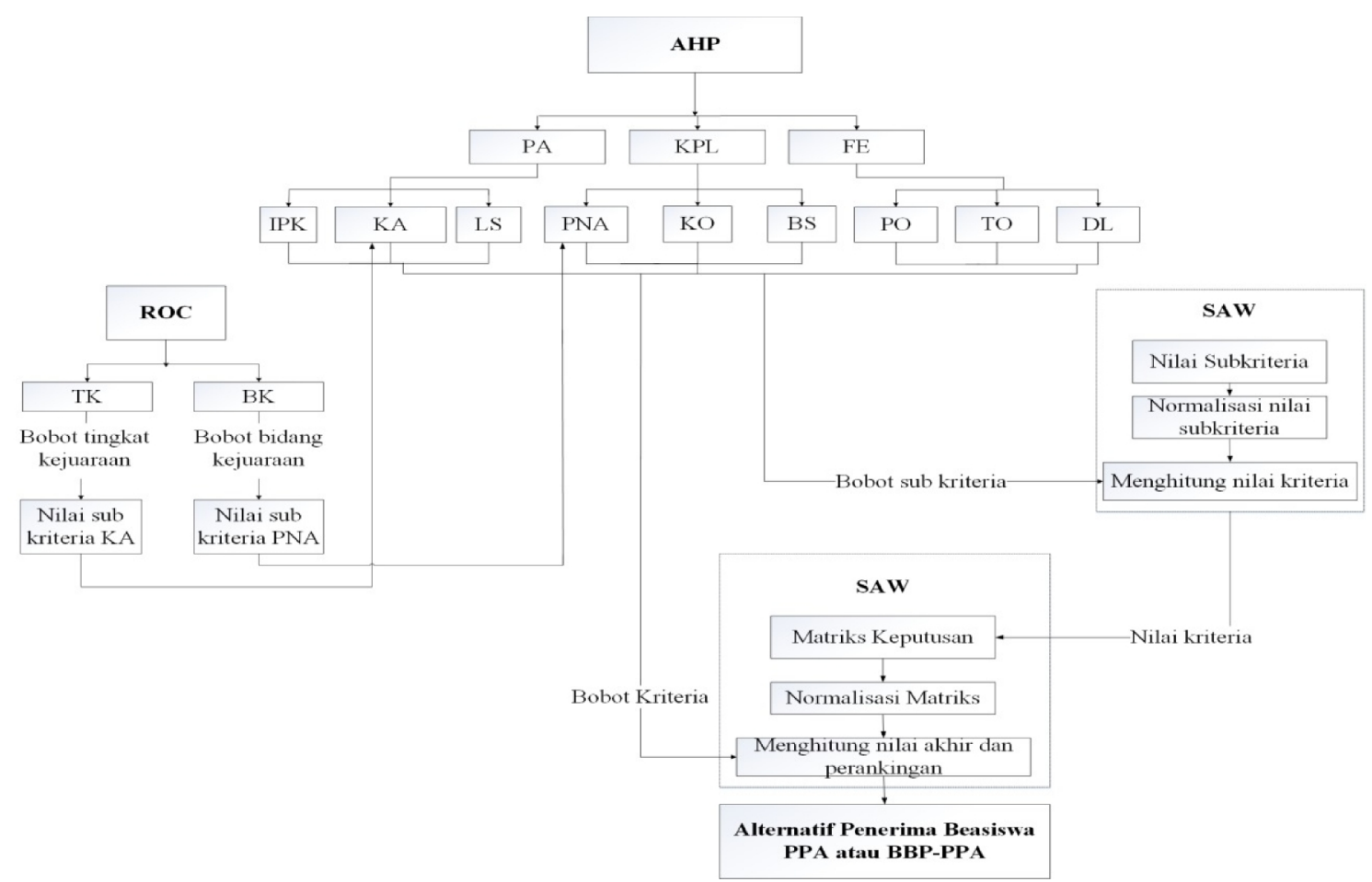

Gambar 2. Gambaran umum model SPK pemberian beasiswa PPA dan BBP

Berdasarkan Gambar 2 maka dapat dijelaskan Perhitungan ROC digunakan untuk scoring data teks tingkat kejuaraan dan bidang kejuaraan yaitu dengan menentukan bobot tingkat kejuaraan, nilai bobot tingkat kejuaraan nantinya akan dikalikan dengan indikator juara sehingga menghasilkan nilai subkriteria prestasi akademik. Kriteria yang memiliki sub kriteria akan dicari bobot sub kriterianya terlebih dahulu menggunakan metode AHP, hasil pembobotan sub kriteria tersebut akan digunakan untuk mendapatkan nilai kriteria. Nilai kriteria yang memiliki sub kriteria diperoleh dengan melakukan normalisasi nilai subkriteria berdasarkan jenis subkriteria, kemudian menjumlahkan hasil kali nilai subkriteria yang telah ternormalisasi dengan bobot subkriteria yang dihasilkan dari perhitungan metode AHP. Kriteria prestasi akademik, kegiatan pendukung lainnya dan faktor ekonomi dihitung bobotnya dengan metode AHP sehingga menghasilkan nilai bobot kriteria. Hasil pembobotan tiap kriteria akan digunakan dalam proses perhitungan nilai akhir menggunakan metode SAW. Proses perhitungan nilai akhir metode SAW yaitu melakukan proses pembuatan matriks keputusan berdasarkan alternatif mahasiswa dan nilai kinerja mahasiswa dari tiap kriteria. Melakukan normalisasi matriks berdasarkan sifat kriteria, hasil normalisasi matriks akan digunakan untuk perhitungan nilai akhir dengan cara menjumlahkan hasil kali antara nilai matriks normalisasi dengan bobot dari tiap kriteria yang didapat dari proses perhitungan metode AHP, kemudian melakukan hasil akhir dan melakukan perankingan berdasarkan hasil akhir.

\section{HASIL DAN PEMBAHASAN}

Perhitungan Bobot Kriteria dengan AHP

Berdasarkan pada prosedur AHP, maka langkah 1 akan dibuat matriks perbandingan berpasangan kriteria, dapat dilihat pada Tabel 5 berikut : 
Tabel 5. Matriks Perbandingan Berpasangan Kriteria

\begin{tabular}{|c|c|c|c|}
\hline Kriteria & $\begin{array}{c}\text { Kegiatan pendukung } \\
\text { lainnya }\end{array}$ & $\begin{array}{c}\text { Prestasi } \\
\text { akademik }\end{array}$ & Faktor ekonomi \\
\hline $\begin{array}{c}\text { Kegiatan pendukung } \\
\text { lainnya }\end{array}$ & 1 & 0,5 & 2 \\
\hline Prestasi akademik & 2 & 1 & 2 \\
\hline Faktor ekonomi & 0,5 & 0,5 & 1 \\
\hline
\end{tabular}

Untuk menentukan bobot prioritas kriteria menggunakan Persamaan 3, sehingga bobot yang dihasilkan sebagai berikut :

$$
\begin{aligned}
& \text { Bobot Kegiatan Pendukung } \\
& \text { Lainnya }=0,31081 \\
& \text { Bobot Prestasi Akademik = } \\
& 0,49339 \\
& \text { Bobot Faktor Ekonomi = } \\
& 0,1958
\end{aligned}
$$

Untuk mencari nilai $\lambda_{\text {maks }}$ menggunakan Persamaan 4, perhitungannya sebagai berikut :

$$
\begin{aligned}
\lambda_{\text {maks }}=((1+ & 2+0,5) \times 0,31081)+((0,5 \\
& +1+0,5) \times 0,49339)+(( \\
& 2+2+1) \times 0,1958)=3,05
\end{aligned}
$$

Model Perhitungan Bobot Tingkat Kejuaraan dan Bidang Kejuaraan dengan ROC

Tingkat kejuaraan digunakan untuk menentukan nilai subkriteria prestasi akademik $=$ (nilai indikator juara $\mathrm{x}$ bobot tingkat kejuaraan ), untuk menentukan bobot dengan ROC maka urutan peringkat atribut atau kriteria sudah diketahui secara by nature. Dalam penelitian ini urutan prioritas tingkat kejuaraan dimulai dengan tingkat Internasional, kemudian nasional, propinsi, lokal hingga non prestasi.
Selanjutnya menghitung Consistency Index (CI) menggunakan Persamaan 5, perhitungannya sebagai berikut :

$$
C=\frac{3,05-3}{3-1}=0,02
$$

Menghitung Consistency Ratio (CR) menggunakan Persamaan 6. Ratio index (RI) yang digunakan adalah 0,58 karena jumlah kriteria (n) $=3$, perhitungan $\mathrm{CR}$ sebagai berikut :

$$
\mathrm{CR}=\frac{0,0}{0,5}=0,04 \text {, nilai } \mathrm{CR}
$$
menunjukkan $\leq 0,1$ yang menunjukkan konsisten.

Dengan cara yang sama menggunakan metode AHP untuk menentukan nilai bobot subkriteria.

Perhitungan bobot tingkat kejuaraan sesuai dengan Persamaan $7, \mathrm{~W}_{1}$ menunjukkan nilai bobot untuk atribut urutan prioritas ke-1 dengan perhitungan 1/banyak atribut kemudian dikalikan dengan jumlah total dari $1 / \mathrm{i}$, karena menggunakan 5 atribut maka nilai i dimulai dari 1 sampai 5 , sehingga untuk menentukan nilai $\mathrm{W}_{1}$ maka jumlah total $1 /$ i dimulai dari $1 / 1$ hingga $1 / 5$, kemudian untuk $\mathrm{W}_{2}$ dimulai dari $1 / 2$ hingga $1 / 5$, dan seterusnya untuk menentukan $\mathrm{W}_{3}$ sampai $\mathrm{W}_{5}$. Perhitungan bobot tingkat kejuaraan dapat dilihat pada Tabel 3.2 berikut :

Tabel 6. Perhitungan Bobot Tingkat Kejuaraan

\begin{tabular}{|c|c|}
\hline Urutan prioritas tingkat kejuaraan & Bobot \\
\hline Internasional & $\mathrm{W}_{1}=\frac{1}{5} \times\left(\frac{1}{1}+\frac{1}{2}+\frac{1}{3}+\frac{1}{4}+\frac{1}{5}\right)=0,45667$ \\
\hline Nasional & $\mathrm{W}_{2}=\frac{1}{5} \times\left(0+\frac{1}{2}+\frac{1}{3}+\frac{1}{4}+\frac{1}{5}\right)=0,25667$ \\
\hline Propinsi & $\mathrm{W}_{3}=\frac{1}{5} \times\left(0+0+\frac{1}{3}+\frac{1}{4}+\frac{1}{5}\right)=0,15667$ \\
\hline Lokal & $\mathrm{W}_{4}=\frac{1}{5} \times\left(0+0+0+\frac{1}{4}+\frac{1}{5}\right)=0,09$ \\
\hline Non prestasi & $\mathrm{W}_{5}=\frac{1}{5} \times\left(0+0+0+0+\frac{1}{5}\right)=0,04$ \\
\hline
\end{tabular}

Dengan cara yang sama maka bobot bidang kejuaraan ditentukan dengan ROC, pada penelitian ini urutan prioritas bidang kejuaraan ditentukan oleh pengambil keputusan dengan urutan bidang olahraga, kemudian seni, budaya, dan lain-lain, hingga non prestasi. 


\section{Model Penilaian Keaktifan Organisasi dan Indikator Juara}

Keaktifan organisasi mahasiswa dilihat dari keikut sertaan didalam organisasi intra kampus, maka penilaiannya ditentukan dengan skala 1 sampai 5, untuk jabatan organisasi ketua BEM atau UKM diberi nilai 5, wakil ketua BEM atau UKM diberi nilai 4, bendahara atau sekretaris BEM atau UKM diberi nilai 3, hanya sebagai anggota BEM atau UKM diberi nilai 2, dan tidak mengikuti organisasi manapun diberikan nilai 1.

Dengan cara yang sama maka model penilaian indikator juara ditentukan dengan menggunakan nilai skala 4 untuk indikator juara 1, nilai 3 untuk indikator juara 2, nilai 2 untuk indikator juara 3 , nilai 1 untuk indikator hanya berpartisipasi.

\section{Model Penilaian Penghasilan Orangtua dan Daya Listrik}

Pada penelitian ini penilaian penghasilan orangtua dan daya listrik menggunakan interpolasi linier yang sesuai dengan Persamaan 12 dimana diketahui nilai $y_{1}=3, y_{0}=1, x_{1}=5000000$ dan $x_{0}=$ 500000, contoh perhitungannya sebagai berikut :

$$
\begin{aligned}
& \text { Nilai penghasilan Rp. } 2000.000= \\
& \frac{(3-1)}{5}(2000000-500000)+1 \\
& =1,6813187
\end{aligned}
$$

\section{Perhitungan Metode SAW}

Untuk melakukan perhitungan metode SAW maka digunakan data mahasiswa pemohon beasiswa PPA yang berjumlah 22 mahasiswa dapat dilihat pada Tabel 7 dan data mahasiswa pemohon beasiswa BBP berjumlah 20 orang dapat dilihat pada Tabel

\begin{tabular}{|c|c|c|c|c|c|c|c|c|c|}
\hline \multirow[t]{2}{*}{ Nama } & \multicolumn{3}{|c|}{ K1 } & \multicolumn{3}{|c|}{$\mathrm{K} 2$} & \multicolumn{3}{|c|}{ K3 } \\
\hline & SK1 & SK2 & SK3 & SK4 & SK5 & SK6 & SK7 & SK8 & SK9 \\
\hline Christopher & 3,86 & non prestasi & 6 & juara 3 olahraga & anggota UKM & 1 & Rp2.000.000 & 2 & 1200 \\
\hline Ester & 3,95 & partisipasi propinsi & 6 & non prestasi & anggota BEM & 2 & Rp3.000.000 & 1 & 1200 \\
\hline Adi & 3,37 & non prestasi & 6 & non prestasi & anggota UKM & 1 & Rp2.000.000 & 2 & 1200 \\
\hline Juliana & 3,34 & non prestasi & 6 & non prestasi & anggota UKM & 1 & Rp2.000.000 & 1 & 1200 \\
\hline Alit & 3,7 & partisipasi lokal & 6 & non prestasi & anggota UKM & 1 & Rp3.000.000 & 2 & 900 \\
\hline Putu & 3,36 & partisipasi lokal & 6 & non prestasi & anggota BEM & 2 & Rp3.000.000 & 2 & 1200 \\
\hline Sisca & 3,58 & non prestasi & 6 & juara 3 budaya & anggota UKM & 2 & Rp500.000 & 1 & 1200 \\
\hline Dian & 3,48 & non prestasi & 6 & $\begin{array}{c}\text { partisipasi } \\
\text { budaya }\end{array}$ & anggota UKM & 2 & Rp1.200.000 & 1 & 1200 \\
\hline Jonathan & 3,38 & non prestasi & 6 & juara 1 olahraga & anggota UKM & 1 & Rp1.300.000 & 1 & 1200 \\
\hline Mahesa & 3,81 & $\begin{array}{c}\text { partisipasi } \\
\text { internasional }\end{array}$ & 6 & non prestasi & anggota BEM & 1 & Rp4.166.667 & 1 & 1200 \\
\hline Ana & 3,69 & partisipasi propinsi & 4 & non prestasi & anggota BEM & 2 & Rp2.000.000 & 2 & 1200 \\
\hline Ayudani & 3,88 & juara 3 propinsi & 4 & non prestasi & anggota BEM & 2 & Rp3.000.000 & 2 & 1200 \\
\hline Eka & 3,96 & partisipasi lokal & 4 & non prestasi & anggota UKM & 2 & Rp2.000.000 & 3 & 1200 \\
\hline Dessie & 3,51 & non prestasi & 4 & juara 3 seni & anggota BEM & 2 & Rp5.000.000 & 2 & 1200 \\
\hline Ayu & 3,71 & partisipasi nasional & 4 & non prestasi & anggota BEM & 2 & Rp2.000.000 & 2 & 1200 \\
\hline Julius & 3,79 & non prestasi & 4 & $\begin{array}{c}\text { partisipasi } \\
\text { budaya }\end{array}$ & anggota BEM & 1 & Rp1.500.000 & 3 & 1200 \\
\hline Ita & 3,65 & non prestasi & 4 & juara 2 olahraga & $\begin{array}{c}\text { bendahara } \\
\text { BEM }\end{array}$ & 2 & Rp1.500.000 & 3 & 1200 \\
\hline Lina & 3,9 & non prestasi & 4 & juara 2 seni & anggota UKM & 2 & Rp2.500.000 & 2 & 1200 \\
\hline Yusuf & 3,52 & juara 1 nasional & 4 & non prestasi & anggota BEM & 2 & Rp2.083.333 & 2 & 1200 \\
\hline Yulia & 3,66 & non prestasi & 4 & $\begin{array}{c}\text { partisipasi } \\
\text { budaya }\end{array}$ & anggota UKM & 2 & Rp2.500.000 & 2 & 1200 \\
\hline Meilina & 3,82 & non prestasi & 4 & juara 3 seni & anggota BEM & 2 & Rp1.333.333 & 2 & 1200 \\
\hline Yoseph & 3,75 & non prestasi & 2 & $\begin{array}{c}\text { partisipasi } \\
\text { budaya }\end{array}$ & anggota BEM & 2 & Rp2.750.000 & 3 & 1200 \\
\hline
\end{tabular}
8 sebagai berikut :

Tabel 7. Data Mahasiswa Pemohon Beasiswa PPA

Tabel 8. Data Mahasiswa Pemohon Beasiswa BBP 


\begin{tabular}{|c|c|c|c|c|c|c|c|c|c|}
\hline \multirow[t]{2}{*}{ Nama } & \multicolumn{3}{|c|}{ K1 } & \multicolumn{3}{|c|}{$\mathrm{K} 2$} & \multicolumn{3}{|c|}{ K3 } \\
\hline & SK1 & SK2 & SK3 & SK4 & SK5 & SK6 & SK7 & SK8 & SK9 \\
\hline Rizal & 3,85 & non prestasi & 6 & non prestasi & anggota UKM & 3 & Rp800.000 & 1 & 450 \\
\hline Wayan Tony & 3,59 & non prestasi & 6 & non prestasi & anggota BEM & 1 & Rp1.000.000 & 4 & 450 \\
\hline Dewa Ray & 3,75 & non prestasi & 6 & non prestasi & anggota BEM & 1 & Rp1.666.667 & 1 & 450 \\
\hline $\begin{array}{l}\text { Samsul } \\
\text { Hakim }\end{array}$ & 3,09 & non prestasi & 6 & non prestasi & anggota UKM & 2 & Rp1.200.000 & 3 & 900 \\
\hline $\begin{array}{l}\text { Komang } \\
\text { Dodik }\end{array}$ & 3,29 & non prestasi & 6 & non prestasi & anggota UKM & 2 & Rp1.200.000 & 2 & 900 \\
\hline Putu Etin $\mathrm{H}$ & 3,54 & non prestasi & 6 & non prestasi & anggota UKM & 1 & Rp666.667 & 4 & 450 \\
\hline Putu Armita & 3,53 & non prestasi & 6 & non prestasi & anggota BEM & 1 & Rp1.000.000 & 2 & 900 \\
\hline Made Anyar & 3,7 & non prestasi & 6 & non prestasi & anggota BEM & 2 & Rp1.500.000 & 2 & 900 \\
\hline \begin{tabular}{|l|} 
Made \\
Adiguna
\end{tabular} & 3,34 & non prestasi & 6 & non prestasi & anggota BEM & 1 & Rp1.833.333 & 2 & 450 \\
\hline \begin{tabular}{|l|} 
Rofinus \\
Seran
\end{tabular} & 3,44 & non prestasi & 4 & non prestasi & anggota BEM & 1 & Rp1.333.333 & 4 & 900 \\
\hline Gede Sri & 3,45 & non prestasi & 4 & non prestasi & anggota UKM & 1 & Rp1.200.000 & 1 & 900 \\
\hline Suci Astiti & 3,84 & non prestasi & 4 & non prestasi & anggota BEM & 1 & Rp1.500.000 & 1 & 900 \\
\hline Arnoldena & 3,62 & non prestasi & 4 & non prestasi & anggota UKM & 2 & Rp500.000 & 4 & 450 \\
\hline Ni Kadek W & 3,71 & non prestasi & 4 & non prestasi & anggota BEM & 2 & Rp500.000 & 2 & 450 \\
\hline Dewa Made & 3,22 & non prestasi & 4 & non prestasi & anggota BEM & 2 & Rp1.800.000 & 4 & 900 \\
\hline Ni Kadek W & 3,28 & non prestasi & 4 & non prestasi & anggota BEM & 2 & Rp916.667 & 1 & 900 \\
\hline Anggreni & 3,46 & non prestasi & 4 & non prestasi & anggota UKM & 1 & Rp1.500.000 & 5 & 450 \\
\hline Putu Eka P & 3,3 & non prestasi & 2 & non prestasi & anggota BEM & 2 & Rp833.333 & 4 & 450 \\
\hline Ernawati & 3,25 & non prestasi & 2 & non prestasi & anggota BEM & 2 & Rp1.500.000 & 4 & 900 \\
\hline Maria Polly & 3,7 & non prestasi & 2 & non prestasi & anggota UKM & 2 & Rp1.000.000 & 4 & 900 \\
\hline
\end{tabular}

Keterangan :

K1 : Prestasi akademik

seminar

K2 : Kegiatan pendukung lainnya orangtua

K3 : Faktor ekonomi

orangtua
SK1 : IPK

SK2 : Kejuaraan akademik

SK3 : Lama studi

SK5 : Keaktifan organisasi
SK6: Banyaknya

SK7: Penghasilan

SK8: Tanggungan

SK9: Daya listrik
Berdasarkan Tabel 7 dan Tabel 8 maka dapat dilihat data mahasiswa pemohon beasiswa PPA dan BBP, namun masih terdapat data dalam bentuk teks, sehingga perlu dilakukan skoring menjadi angka, contohnya alternatif christopher memiliki nilai SK1 yaitu non prestasi maka akan dilakukan skoring sesuai dengan penjelasan Sub bab 3.3, tingkat kejuaraan non prestasi akan dirubah menjadi nilai 0,04 , untuk nilai SK4 adalah juara 3 olahraga maka akan dirubah dengan mengalikan indikator juara 3 yaitu nilai 3 dengan bobot bidang kejuaraan olahraga sehingga menjadi nilai 1,04167 , kemudian nilai SK5 adalah anggota UKM akan dirubah dalam skala nilai 1 , nilai SK7 yaitu penghasilan Rp.1200.000 akan dirubah menggunakan interpolasi linier sehingga menghasilkan nilai 1,6813187 dan nilai SK9 yaitu daya listrik 1200 akan dirubah menggunakan interpolasi linier sehingga menghasilkan nilai 1,491803279. Dengan cara yang sama maka nilai alternatif yang lain yang masih dalam bentuk teks akan dirubah kedalam angka.

Matriks Keputusan dan Perankingan Metode SAW

Perhitungan metode SAW untuk mendapatkan nilai akhir dan perankingan. Perhitungan metode SAW dengan membuat matriks keputusan, dapat dilihat pda Tabel 9. berikut : 
Tabel 9. Matriks Keputusan Alternatif Beasiswa PPA

\begin{tabular}{|c|c|c|c|c|c|c|c|c|c|}
\hline & $\mid$ SK1 & SK2 & SK3 & SK4 & SK5 & SK6 & SK7 & SK8 & SK9 \\
\hline Christopher & 3,86 & 0,04 & 6 & 1,041666667 & 2 & 1 & 1,681318681 & 2 & 1,491803279 \\
\hline Ester & 3,95 & 0,156666667 & 6 & 0,0625 & 2 & 2 & 2,120879121 & 1 & 1,491803279 \\
\hline Adi & 3,37 & 0,04 & 6 & 0,0625 & 2 & 1 & 1,681318681 & 2 & 1,491803279 \\
\hline Juliana & 3,34 & 0,04 & 6 & 0,0625 & 2 & 1 & 1,681318681 & 1 & 1,491803279 \\
\hline Alit & 3,7 & 0,09 & 6 & 0,0625 & 2 & 1 & 2,120879121 & 2 & 1,295081967 \\
\hline Putu & 3,36 & 0,09 & 6 & 0,0625 & 2 & 2 & 2,120879121 & 2 & 1,491803279 \\
\hline Sisca & 3,58 & 0,04 & 6 & 0,541666667 & 2 & 2 & 1,021978022 & 1 & 1,491803279 \\
\hline Dian & 3,48 & 0,04 & 6 & 0,270833333 & 2 & 2 & 1,32967033 & 1 & 1,491803279 \\
\hline Jonathan & 3,38 & 0,04 & 6 & 2,083333333 & 2 & 1 & 1,373626374 & 1 & 1,491803279 \\
\hline Mahesa & 3,81 & 0,456666667 & 6 & 0,0625 & 2 & 1 & 2,63369978 & 1 & 1,491803279 \\
\hline Ana & 3,69 & 0,156666667 & 4 & 0,0625 & 2 & 2 & 1,681318681 & 2 & 1,491803279 \\
\hline Ayudani & 3,88 & 0,313333333 & 4 & 0,0625 & 2 & 2 & 2,120879121 & 2 & 1,491803279 \\
\hline Eka & 3,96 & 0,09 & 4 & 0,0625 & 2 & 2 & 1,681318681 & 3 & 1,491803279 \\
\hline Dessie & 3,51 & 0,04 & 4 & 0,291666667 & 2 & 2 & 3 & 2 & 1,491803279 \\
\hline Ayu & 3,71 & 0,2566666667 & 4 & 0,0625 & 2 & 2 & 1,681318681 & 2 & 1,491803279 \\
\hline Julius & 3,79 & 0,04 & 4 & 0,270833333 & 2 & 1 & 1,461538462 & 3 & 1,491803279 \\
\hline Ita & 3,65 & 0,04 & 4 & 1,5625 & 3 & 2 & 1,461538462 & 3 & 1,491803279 \\
\hline Lina & 3,9 & 0,04 & 4 & 0,4375 & 2 & 2 & 1,901098901 & 2 & 1,491803279 \\
\hline Yusuf & 3,52 & 1,026666667 & 4 & 0,0625 & 2 & 2 & 1,717948571 & 2 & 1,491803279 \\
\hline Yulia & 3,66 & 0,04 & 4 & 0,270833333 & 2 & 2 & 1,901098901 & 2 & 1,491803279 \\
\hline Meilina & 3,82 & 0,04 & 4 & 0,291666667 & 2 & 2 & 1,388278242 & 2 & 1,491803279 \\
\hline Yoseph & 3,75 & 0,04 & 2 & 0,270833333 & 2 & 2 & 2,010989011 & 3 & 1,491803279 \\
\hline
\end{tabular}

Matriks keputusan diperoleh dari data mahasiswa yang sudah dirubah kedalam angka, selanjutnya matriks keputusan akan dinormalisasi sesuai dengan Persamaan 9 yaitu sifat benefit untuk SK1, SK2, SK3, SK4, SK5,SK6 dan SK8 serta sifat cost untuk SK7 dan SK9 untuk beasiswa PPA, setelah didapatkan matriks ternorma-lisasi maka akan ditentukan nilai kriteria sesuai dengan Persamaan 8 yaitu dengan mengalikan matriks ternormalisasi dengan bobot subkriteria yang telah ditentukan dengan metode AHP.

Tabel 10. Matriks Keputusan Alternatif Beasiswa PPA

\begin{tabular}{|l|c|c|c|c|c|c|c|c|c|}
\hline & SK1 & SK2 & SK3 & SK4 & SK5 & SK6 & SK7 & SK8 & SK9 \\
\hline Rizal & 3,85 & 0,04 & 6 & 0,0625 & 2 & 3 & 1,153846154 & 1 & 1 \\
\hline Wayan Tony & 3,59 & 0,04 & 6 & 0,0625 & 2 & 1 & 1,241758242 & 4 & 1 \\
\hline Dewa Ray & 3,75 & 0,04 & 6 & 0,0625 & 2 & 1 & 1,534798681 & 1 & 1 \\
\hline $\begin{array}{l}\text { Samsul } \\
\text { Hakim }\end{array}$ & 3,09 & 0,04 & 6 & 0,0625 & 2 & 2 & 1,32967033 & 3 & 1,295081967 \\
\hline $\begin{array}{l}\text { Komang } \\
\text { Dodik }\end{array}$ & 3,29 & 0,04 & 6 & 0,0625 & 2 & 2 & 1,32967033 & 2 & 1,295081967 \\
\hline $\begin{array}{l}\text { Putu Etin H } \\
\text { Putu Armita }\end{array}$ & 3,54 & 0,04 & 6 & 0,0625 & 2 & 1 & 1,095238242 & 4 & 1 \\
\hline Made Anyar & 3,7 & 0,04 & 6 & 0,0625 & 2 & 2 & 1,461538462 & 2 & 1,295081967 \\
\hline $\begin{array}{l}\text { Made } \\
\text { Adiguna }\end{array}$ & 3,34 & 0,04 & 6 & 0,0625 & 2 & 1 & 1,608058462 & 2 & 1 \\
\hline $\begin{array}{l}\text { Rofinus } \\
\text { Seran }\end{array}$ & 3,44 & 0,04 & 4 & 0,0625 & 2 & 1 & 1,388278242 & 4 & 1,295081967 \\
\hline Gede Sri & 3,45 & 0,04 & 4 & 0,0625 & 2 & 1 & 1,32967033 & 1 & 1,295081967 \\
\hline Suci Astiti & 3,84 & 0,04 & 4 & 0,0625 & 2 & 1 & 1,461538462 & 1 & 1,295081967 \\
\hline Arnoldena & 3,62 & 0,04 & 4 & 0,0625 & 2 & 2 & 1,021978022 & 4 & 1 \\
\hline Ni Kadek W & 3,71 & 0,04 & 4 & 0,0625 & 2 & 2 & 1,021978022 & 2 & 1 \\
\hline
\end{tabular}




\begin{tabular}{|l|c|c|c|c|c|c|c|c|c|}
\hline & SK1 & SK2 & SK3 & SK4 & SK5 & SK6 & SK7 & SK8 & SK9 \\
\hline Dewa Made & 3,22 & 0,04 & 4 & 0,0625 & 2 & 2 & 1,593406593 & 4 & 1,295081967 \\
\hline Ni Kadek W & 3,28 & 0,04 & 4 & 0,0625 & 2 & 2 & 1,205128352 & 1 & 1,295081967 \\
\hline Anggreni & 3,46 & 0,04 & 4 & 0,0625 & 2 & 1 & 1,461538462 & 4 & 1 \\
\hline Putu Eka P & 3,3 & 0,04 & 2 & 0,0625 & 2 & 2 & 1,168498022 & 4 & 1 \\
\hline Ernawati & 3,25 & 0,04 & 2 & 0,0625 & 2 & 2 & 1,461538462 & 4 & 1,295081967 \\
\hline Maria Polly & 3,7 & 0,04 & 2 & 0,0625 & 2 & 2 & 1,241758242 & 4 & 1,295081967 \\
\hline
\end{tabular}

Proses akhir metode SAW sesuai dengan Persamaan 10, yaitu dengan mengalikan nilai kriteria dengan bobot kriteria yang telah ditentukan pada penjelasan Sub Bab 3.2, sehingga didapatkan nilai akhir (Vi) untuk setiap alternatif terhadap setiap kriteria dan dilakukan perankingan dengan mengurutkan nilai terbesar hingga terkecil. Nilai akhir (Vi) dan perankingan alternatif mahasiswa pemohon beasiswa PPA dapat dilihat pada Tabel 11 sebagai berikut :

Tabel 11. Nilai Akhir dan Perankingan Alternatif Beasiswa PPA

\begin{tabular}{|c|c|c|}
\hline Alternatif & Vi & Rank \\
\hline Christopher & 0,742104157 & 5 \\
\hline Ester & 0,680632613 & 12 \\
\hline Adi & 0,625655857 & 20 \\
\hline Juliana & 0,599814837 & 22 \\
\hline Alit & 0,646053234 & 18 \\
\hline Putu & 0,651842526 & 17 \\
\hline Sisca & 0,742304214 & 4 \\
\hline Dian & 0,682613566 & 11 \\
\hline Jonathan & 0,789919815 & 3 \\
\hline Mahesa & 0,674918592 & 13 \\
\hline Ana & 0,665929713 & 15 \\
\hline Ayudani & 0,689485639 & 8 \\
\hline Eka & 0,697220651 & 6 \\
\hline Dessie & 0,618195393 & 21 \\
\hline Ayu & 0,684302265 & 9 \\
\hline Julius & 0,671474942 & 14 \\
\hline Ita & 0,841592201 & 1 \\
\hline Lina & 0,68318399 & 10 \\
\hline Yusuf & 0,800060313 & 2 \\
\hline Yulia & 0,652422964 & 16 \\
\hline Meilina & 0,691063003 & 7 \\
\hline Yoseph & 0,642055449 & 19 \\
\hline & & \\
\hline
\end{tabular}

Nilai akhir (Vi) dan perankingan alternatif mahasiswa pemohon beasiswa

BPP dapat dilihat pada Tabel 12 sebagai berikut :

Tabel 12. Nilai Akhir dan Perankingan Alternatif Beasiswa BBP

\begin{tabular}{|l|c|c|}
\hline \multicolumn{1}{|c|}{ Alternatif } & Vi & Rank \\
\hline Rizal & 0,862381 & 8 \\
\hline Wayan Tony & 0,822919 & 3 \\
\hline Dewa Ray & 0,680255 & 18 \\
\hline Samsul Hakim & 0,779378 & 10 \\
\hline Komang Dodik & 0,755586 & 14 \\
\hline Putu Etin H & 0,854446 & 2 \\
\hline Putu Armita & 0,730328 & 11 \\
\hline Made Anyar & 0,75519 & 15 \\
\hline Made Adiguna & 0,683855 & 16 \\
\hline Rofinus Seran & 0,733958 & 9 \\
\hline Gede Sri & 0,642296 & 19 \\
\hline
\end{tabular}




\begin{tabular}{|l|r|c|}
\hline Suci Astiti & 0,640872 & 20 \\
\hline Arnoldena & 0,900733 & 1 \\
\hline Ni Kadek W & 0,83721 & 17 \\
\hline Dewa Made & 0,747747 & 12 \\
\hline Ni Kadek W & 0,712604 & 17 \\
\hline Anggreni & 0,77899 & 6 \\
\hline Putu Eka P & 0,812455 & 5 \\
\hline Ernawati & 0,73422 & 13 \\
\hline Maria Polly & 0,795685 & 7 \\
\hline Rizal & 0,862381 & 8 \\
\hline Wayan Tony & 0,822919 & 19 \\
\hline
\end{tabular}

\section{SIMPULAN}

Sistem yang dikembangkan menggunakan metode AHP, ROC dan SAW sudah mampu berjalan dengan benar, sehingga sistem ini dapat digunakan sebagai rekomendasi bagi Puket III untuk menentukan alternatif mahasiswa terbaik penerima beasiswa PPA dan BBP. Perbandingan pengujian yang dilakukan pada penelitian menunjukkan bahwa perhitungan model SPK yang dilakukan sistem menghasilkan keputusan yang lebih baik dikarenakan adanya penambahan kriteria yang digunakan pada penelitian dan pemberian bobot yang dilakukan dengan perhitungan metode yang digunakan pada penelitian. Semakin banyak kriteria penilaian yang digunakan untuk seleksi akan menghasilkan alternatif keputusan paling sesuai dengan persyaratan yang telah ditentukan.

\section{DAFTAR PUSTAKA}

[1] Kusrini, 2007, Konsep dan Aplikasi Sistem Pendukung Keputusan, Yogyakarta, C.V Andi Offset.

[2] Yeh,C.H., 2003, The Selection of Multiattribute Decision Making Methods for Scholarship Student Selection, International Journal of Selection and Assessment, vol 4, hal 289-296.

[3] Keeney, R, L. dan Raiffa, H., 1976, Decision With Multiple Objective : preference and value tradeoffs, John Wiley and Sons, Inc., New York.

[4] Lengkong, S.P., 2016, Sistem Pendukung Keputusan Dinamis Untuk Seleksi Penerima Beasiswa Menggunakan Kombinasi Metode AHP dan VIKOR, Tesis, Program
Pasca Sarjana Teknologi Informasi, Univ. Gadjah Mada, Yogyakarta.

[5] Afshari, A., Mohajed, M. dan Yusuff, R.M., 2010, Simple Additive Weighting approach to Personnel Selection Problem, International Journal of Innovation Management and Technology, vol 1, 511-515.

[6] Turban, E., Aronson, J.E. dan Liang, P.T., 2005, Decision Support System and Intelligent System (Sistem Pendukung Keputusan dan Sistem Cerdas), Vol 1, Ed. 7, diterjemahkan oleh Dwi Prabantini, Andi Offset, Yogyakarta.

[7] McLeod, R.Jr., Schell, G.P,. 2007, Management Information System, Ed. 10, Prentice Hall Inc, Upper Saddle River, New Jersey.

[8] Saaty, T.L, 2007, Fundamentals of Decision Making and Priority Theory with the Analytic Hierarchy Process, Vol 6, RWS Publication, America.

[9] Kusumadewi, S., Hartati, S., Harjoko, A. dan Retantyo, W.,2006, Fuzzy Multi-Attribute Decision Making (FUZZY MADM), Graha Ilmu, Yogyakarta

[10] Barron, F.H. dan Barret, B.E., 1996, Decision quality using ranked attributes weights, Management Science, vol 4, hal 1515-1523.

[11] Fishburn, P.C., 1967, Additive Utilities with Incomplete Product Set: Application to Priorities and Assigments, Institute for Operations Research and the Management Sciences, vol 3, hal 537-542. 